МЕТОдИ

\title{
Preparation of bifunctional silica polymer support for the synthesis of $3^{\prime}$-labeled oligonucleotides
}

\author{
L. V. Dubey, I. Ya. Dubey \\ Institute of Molecular Biology and Genetics, National Academy of Sciences of Ukraine \\ 150 Zabolotnoho str., $03143 \mathrm{Kyiv}$, Ukraine \\ E. mail: dubey@imbg.org.ua
}

\begin{abstract}
Preparation of a silica polymer support with a linker arm containing protected amino and hydroxy groups

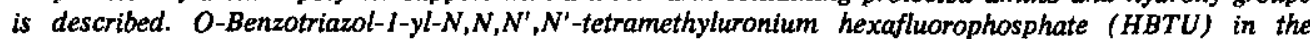
presence of 1-hydroxybenzotriazole (HOBT) was used as an efficient activating reagent at several steps of the polymer synthesis. This bifunctional support is suitable for the preparation of 3'-amino-modified oligonucleotides for post-synthetic conjugation, as well as for the direct solld phase synthesis of $3^{\prime}$-labeled oligonucleotides. The fluorescein-modified silica polymer was synthesized.
\end{abstract}

Key words: polymer supports, onium reagents, labeled ollgonucleotides.

Introduction. Modified oligonucleotides are widely used for DNA sequencing, as nucleic acids probes, PCR primers, gene expression inhibitors, etc. [1]. In the past years non-radioactive labeling, i. e. covalent attachment of fluorescent, chemiluminescent, enzymatic or affinity reporter groups to DNA fragments, has evolved into the preferred method of DNA detection for a wide variety of applications and is believed to replace the use of traditional isotopic labels in the future [2-4]. From this point of view, the development of efficient new approaches and procedures for oligonucleotide labeling is still in great demand. There are two general approaches to the preparation of labeled oligonucleotides $[2,5,6]$. The first one is based on the synthesis and isolation of oligonucleotides, functionalized with amino or mercapto groups, with their post-synthetic conjugation to corresponding molecules. In another method, reporter groups are introduced during solid phase oligonucleotide synthesis followed by the deblocking and purification of resulting conjugate. In this case, the key factor is stability of the attached group during

(C) L. V. DUREY,, I. Ya. DUREY, 2005 oligonucleotide synthesis and deprotection. Recently, the polymer supports containing reporter groups attached via special linkers that allow the elongation of oligonucleotide sequences resulting in the formation of 3'-labeled oligomers have been described, and some of them are currently commercially available (see e. g. [7]). Here we report the preparation of a new silica-based support for the solid phase synthesis of 3'-labeled oligonucleotides. This polymer support can be also used for peptide synthesis.

Materials and Methods. 3-Aminopropane-1,2-diol, O-benzotriazol-1-yl-N,N, $N^{\prime}, N^{\prime}$-tetramethyluronium hexafluorophosphate (HBTU), 1-hydroxybenzotriazole (HOBT), 9-fluorenylmethyl chloroformate (FmocCl) and 4,4'-dimethoxytrityl chloride (DMTr$\mathrm{Cl}$ ) were purchased from «Aldrich» (USA), N-(9-fluorenylmethoxycarbonyl) $\beta$-alanine (Fmoc- $\beta$-Ala) from «Acros Organics» (Belgium), fluorescein-5-isothiocyanate (FITC, isomer I), 1-methylimidazole (MeIm) and pivaloyl chloride (PivCl) were from «Merck» (Germany). Other reagents and solvents were obtained from domestic suppliers. Dimethylformamide (DMF) and MeIm were distilled in vacuo. Piperidine, diisopropylethylamine and dioxane were dried by 
distillation over $\mathrm{NaOH}$. Pyridine was distilled over $\mathrm{NaOH}$, ninhydrin and then $\mathrm{CaH}_{2}$. Column chromatography was performed on Kieselgel 60 silica («Merck»). Absorbance spectra were recorded on Specord UV-Vis spectrophotometer («Karl Zeiss Jena», Germany). Proton NMR spectra were obtained with Bruker AM-250 spectrometer at $250 \mathrm{MHz}$ using tetramethylsilane as external standard.

1-O-(4,4'-Dimethoxytrityl)-2-O-(3-carboxypropionyl)-3-(N-[/9-fluorenylmethyloxy $]$ carbonyl $]$ aminolpropane-1,2-diol 3. $\mathrm{N}$-protection and $\mathrm{O}$-tritylation of 3-aminopropane-1,2-diol 1 were performed by modified procedure [8] (Scheme). Amino group of 3-aminopropane-1,2-diol was protected by the treatment with 9-fluorenylmethyl chloroformate $(0.9 \mathrm{eq}$, 1.2 eq of dissopropylethylamine, DMF, $3 \mathrm{~h}$ at room temperature), and $77 \%$ of N-Fmoc-protected diol was obtained. The primary hydroxyl of $\mathrm{N}$-protected diol was tritylated by standard reaction with $\mathrm{DMTrCl}$ (1.2 eq, pyridine, $4 \mathrm{~h}$ ) and product 2 was isolated by silica gel chromatography (yield $81 \%$ ). 1,3-protected 3-aminopropane-1,2-diol (132 $\mathrm{mg}, 0.21 \mathrm{mmol}$ ) was stirred with succinic anhydride $(42 \mathrm{mg}, 0.42 \mathrm{mmol}$ ) in anhydrous pyridine in the presence of MeIm (17 $\mu \mathrm{l}, 0.21 \mathrm{mmol}$ ) for $4 \mathrm{~h}$.

The reaction mixture was evaporated to dryness, the residue was dissolved in chloroform, organic phase was washed twice with water, dried over $\mathrm{Na}_{2} \mathrm{SO}_{4}$, filtered and evaporated. The crude oil was chromatographed on silica gel using elution with ethylacetate-hexane $2: 1$, ethylacetate and finally ethylacetate-chloroform 1:1. Fractions containing product 3 were evaporated and dried in vacuo over $\mathrm{P}_{2} \mathrm{O}_{5}$ to give a light-yellow solid foam, yield $94 \mathrm{mg}$ $(62 \%)$. M. p. $69-71{ }^{\circ} \mathrm{C}$ (lit. $71-72{ }^{\circ} \mathrm{C}$ [8]). ${ }^{1} \mathrm{H}$ NMR (DMSO- $\mathrm{d}_{6}$ ) $\delta 6.70-7.75(\mathrm{~m}, 21 \mathrm{H}$, aromatic, DMTr, Fmoc), 6.05 (br. s, 1H, NH), 5.11 (m, 1H, $\left.\mathrm{CH}_{2} \mathrm{O}, \mathrm{H}_{\mathrm{a}}\right), 4.30\left(\mathrm{~m}, 1 \mathrm{H}, \mathrm{CH}_{2} \mathrm{O}, \mathrm{H}_{\mathrm{b}}\right), 4.25(\mathrm{~m}, 2 \mathrm{H}$, $\left.\mathrm{CH}_{2} \mathrm{O}, \mathrm{Fmoc}\right), 4.14$ (m, 1H, CH, Fmoc), 3.73 (s, 6H, $\left.\mathrm{OCH}_{3}\right), 3.45(\mathrm{~m}, 1 \mathrm{H}, \mathrm{CHO}), 3.30\left(\mathrm{~m}, 1 \mathrm{H}, \mathrm{CH}_{2} \mathrm{~N}\right.$, $\left.\mathrm{H}_{\mathrm{a}}\right), 3.25\left(\mathrm{~m}, 1 \mathrm{H}, \mathrm{CH}_{2} \mathrm{~N}, \mathrm{H}_{\mathrm{b}}\right), 2.60$ (br. s, 4H, $\mathrm{CH}_{2}$ succinyl).

Coupling of succinate 3 to amino polymer. Silochrom-2 silica containing linker group aminopropylsuccinate-ethylenediamine [9] $\left(\mathrm{NH}_{2}\right.$ loading $48 \mu \mathrm{mol} / \mathrm{g}, 200 \mathrm{mg}$ ), N,O-protected succinate reagent 3 (72 $\mathrm{mg}, 0.1 \mathrm{mmol}$ ), HBTU (38 $\mathrm{mg}, 0.1 \mathrm{mmol}$ ) and 1-hydroxybenzotriazole $(14 \mathrm{mg}, 0.1 \mathrm{mmol})$ in $3 \mathrm{ml}$ DMF were slowly agitated for $4 \mathrm{~h}$ at room temperature. Polymer was filtered off, washed with DMF

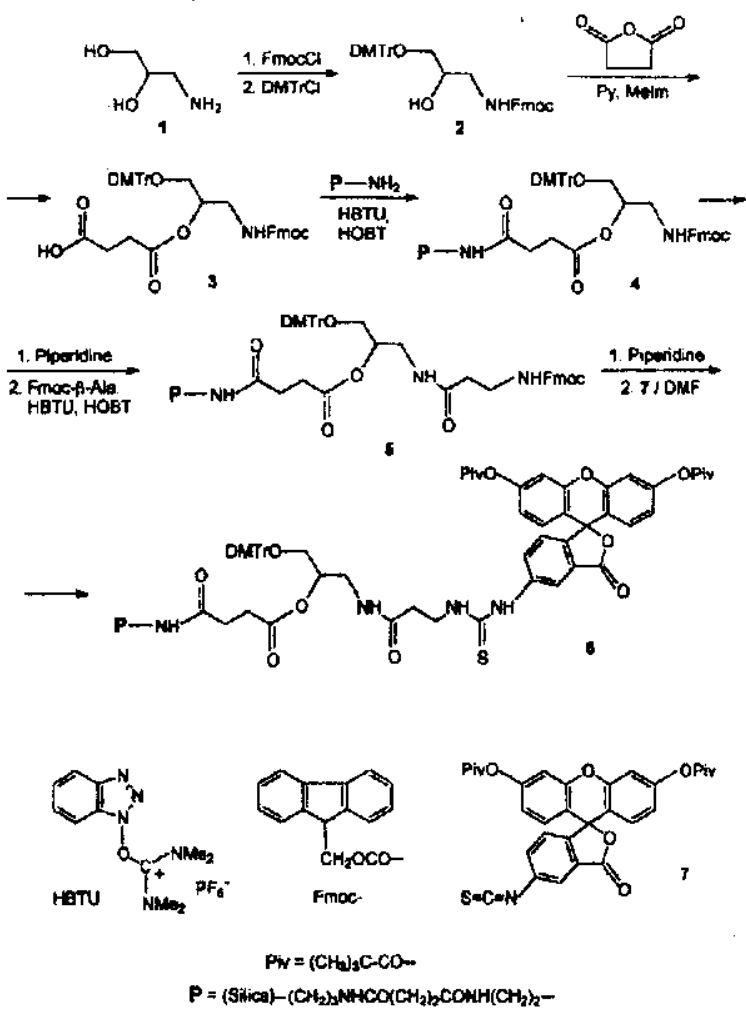

Synthesis of functionalized silica polymer

$(3 \times 3 \mathrm{ml})$ and $\mathrm{CH}_{3} \mathrm{CN}(3 \times 3 \mathrm{ml})$ and treated with a solution of acetic anhydride $(945 \mu 1,10 \mathrm{mmol})$ and MeIm $(795 \mu \mathrm{l}, 10 \mathrm{mmol})$ in $5 \mathrm{ml}$ of acetonitrile with occasional shaking for $30 \mathrm{~min}$ to block unreacted amino groups. Functionalized silica 4 was filtered off, washed with $\mathrm{CH}_{3} \mathrm{CN}(3 \times 3 \mathrm{ml})$, chloroform (3× $\times 3 \mathrm{ml})$, methanol $(3 \times 3 \mathrm{ml})$ and ether $(3 \times 3 \mathrm{ml})$ and dried in vacuo. The succinate loading was $38 \mu \mathrm{mol} / \mathrm{g}$ as determined spectrophotometrically using dimethoxytrityl group acidic cleavage, according to $[10]$.

Attachment of $\beta$-alanyl spacer group to modified silica 4. Polymer support 4 was treated with $20 \%$ piperidine in DMF $(5 \mathrm{ml}, 30 \mathrm{~min}$ at ambient temperture) to remove Fmoc protecting group, washed with $\mathrm{DMF}$, chloroform and ether $(3 \times 3 \mathrm{ml}$ each) and dried in vacuo. Fmoc- $\beta$-alanine ( $31 \mathrm{mg}, 0.1 \mathrm{mmol}$ ) was coupled to $\mathrm{NH}_{2}$-containing polymer by the same procedure as described above for the attachment of succinate reagent, including capping step. Loading Fmoc group determined by treatment of the fraction of polymer 5 with piperidine, and measuring UV absorbance at $302 \mathrm{~nm}$ according to [11] was found to be $33 \mu \mathrm{mol} / \mathrm{g}$. 
3',6'-O-Dipivaloylfluorescein isothiocyanate 7. Dipivaloyl-FITC was prepared according to the procedure published in [12]. Fluorescein-5-isothiocyanate (FITC, isomer I) was treated with $2.5 \mathrm{eq}$ of pivaloyl chloride and 3 eq of diisopropylethylamine in dry THF overnight and product was isolated by silica gel chromatography using elution with chloroform-hexane 4:1 mixture followed by $\mathrm{CHCl}_{3}$. Yellowish foam was obtained after the evaporation of corresponding fractions (yield $64 \%$ ).

Preparation of fluorescein-containing polymer 6. Polymer 5 was treated with $5 \mathrm{ml}$ of $20 \%$ piperidine in DMF for $30 \mathrm{~min}$, washed with DMF $(5 \times 3 \mathrm{ml})$ and treated with the solution of dipivaloyl-FITC $7(56 \mathrm{mg}$, $0.1 \mathrm{mmol}$ ) in $3 \mathrm{ml} \mathrm{DMF}$ for $24 \mathrm{~h}$ at room temperature in the dark with gentle agitation. Support 6 was filtered off, washed with DMF $(5 \times 3 \mathrm{ml})$ and acetonitrile and unreacted amino groups were capped with $5 \mathrm{ml}$ of acetonitrile solution of acetic anhydride (945 $\mu 1,10 \mathrm{mmol}$ ) and MeIm (795 $\mu 1,10 \mathrm{mmol}$ ) for 30 min. Silica was washed with $\mathrm{CH}_{3} \mathrm{CN}, \mathrm{CHCl}_{3}$, $\mathrm{MeOH}$ and ether $(3 \times 3 \mathrm{ml}$ each) and dried in vacuo. Fluorescein content was determined as follows: an aliquot (few $\mathrm{mg}$ ) of the polymer 6 was treated with $200 \mu \mathrm{l}$ of conc. $\mathrm{NH}_{4} \mathrm{OH}$ in the sealed tube overnight at room temperature, the ammonia solution was removed, polymer washed with $0.25 \mathrm{M}$ TEAB buffer, pH $8(4 \times 200 \mu \mathrm{l})$ with centrifugation, and absorbance of combined washings was determined at $494 \mathrm{~nm}$ (for FITC conjugates, $\varepsilon_{494}=75000$ [4]). The dye loading was $28 \mu \mathrm{mol} / \mathrm{g}$.

Results and Discussion. Polymer supports modified with fluorescent dyes including fluorescein and rhodamine have been described in the literature [13-15] and many are commercially available. To prepare the polymer support for the synthesis of $3^{\prime}$-labeled oligonucleotides, a bifunctional linker group should be used allowing the attachment of both reporter molecule and the first nucleotide of the oligonucleotide sequence to the polymer. The linkers are usually based on the structures like 2-substituted 1,3-propanediols. We have used 3-aminopropane-1,2diol 1 for the preparation of the linker (Scheme). This starting synthon contains amino group that can react with many electrophilic reagents in the presence of $\mathrm{OH}$-groups, and then primary hydroxyl can be protected selectively to leave free secondary $\mathrm{OH}$ for the linker attachment to a solid support. The amino group of starting trifunctional compound 1 was protected with Fmoc group by the reaction with Fmoc-chloride in DMF in the presence of diisopropylethylamine, and then $\mathrm{N}$-protected intermediate was tritylated with DMTrCl in pyridine at primary hydroxyl. 1,3-Protected aminodiol 2 was converted into 2-0-succinate 3 by reaction with succinic anhydride in pyridine in the presence of methylimidazole as a catalyst. The use of Melm instead of 4-dimethylaminopyridine (DMAP) improved the yield of succinate $(62 \%)$ since Fmoc group is sensitive to strongly basic DMAP. When DMAP was used, the reported yield was $55 \%$ [8]. NMR spectrum of succinate 3 showed that methylene protons in both $\mathrm{CH}_{2} \mathrm{O}$ and $\mathrm{CH}_{2} \mathrm{~N}$ fragments of aminopropanediol are not equivalent forming $\mathrm{ABX}$ systems with tertiary $\mathrm{CH}$ proton. Before we have observed the same nonequivalence of methylene protons in symmetrical 1,3-ditrityl glycerol (unpublished results).

N,O-protected succinate reagent 3 was attached to the silica support containing aminoalkyl groups. The polymer used for the preparation of modified support was previously described Silochrom-2 silica with the aminopropyl-succinate-ethylenediamine linker [9]. Usually nucleoside succinates are linked to polymers as activated esters or in the presence of coupling reagents like carbodiimides or arylsulfonylchlorides. In the present work, the coupling of succinate to aminated polymer was accomplished using highly efficient uronium coupling reagent HBTU in the presence of HOBT. A variety of phosphonium and uronium reagents have been used in coupling reactions in peptide synthesis [16]. Onium salts are now very popular since they are stable, non-hygroscopic and easy to use coupling reagents. There are numerous examples of the use of these reagents in oligonucleotide synthesis, including nucleoside attachment to solid supports $[8,14,17,18]$ and oligonucleotide functionalization or labeling [1921 ]. We have recently described the synthesis of silica polymer and nucleoside immobilization at this support using onium salts in the presence of HOBT [22]. In the present work, the succinate reagent 3 activated with HBTU reagent was coupled to the aminoalkyl linker of the silica. At this point, the support 4 is ready for the attachment of reporter groups, however we have decided to perform the elongation of spacer arm to improve the yield of conjugation of fluorophores, as well as the yield of the first coupling reaction of the oligonucleotide chain synthesis. NFmoc-protected amino acids were used previously for the spacer elongation [23]. We have utilized $\mathrm{N}$ - 
protected $\beta$-alanine for this purpose. Fmoc protection was removed from the polymer 4 by piperidine treatment. Then Fmoc- $\beta$-alanine was attached to the free $\mathrm{NH}_{2}$ linker group in the presence of the same HBTU/HOBT activating reagent. Fmoc group loading was $33 \mu \mathrm{mol} / \mathrm{g}$.

The silica support 5 containing N,O-protected linker can be used for the preparation of oligonucleotides functionalized with the aliphatic amino group at the 3 '-end for post-synthetic labeling. After detritylation of the support, the oligonucleotide synthesis can be performed on the polymer followed by deprotection of amino group. Deblocked and removed from the support, the aminoalkyl-modified oligonucleotides can be subsequently labeled with any suitable reagent developed for the modification of amino groups including fluorescent dyes, intercalating agents, chemical nucleases, etc. However, it was interesting to prepare a support for the direct solid phase synthesis of $3^{\prime}$-labeled oligonucleotides. For this reason, the linker amino group was deblocked and coupled to the amine-reactive isothiocyanate derivative of the fluorescein dye, FITC. To avoid side reactions at phenolic hydroxyls of fluorescein, they were protected with pivaloyl chloride $[12,13]$. Diacylated FITC lactone 7 is almost colourless and nonfluorescent since the chromophore system of the dye is changed. However, its deacylation upon ammonolysis leads to the recovery of the normal fluorescein structure. Dipivaloyl FITC was efficiently linked to the aminated polymer support in DMF, and remaining $\mathrm{NH}_{2}$ groups were capped with acetic anhydride. The dye content in the resulting polymer 6 was found to be $28 \mu \mathrm{mol} / \mathrm{g}$. After detritylation, the silica support with a free hydroxy group is suitable for the 'solid phase oligonucleotide synthesis to produce $3^{\prime}$-fluorescein labeled oligonucleotides.

It should be stressed that silica polymer 5 is the bifunctional support containing both protected $\mathrm{OH}$ and $\mathrm{NH}_{2}$ functions and therefore can be also used for the solid phase synthesis of peptides at the amino linker. The peptide chain elongation can be performed after deprotection of the polymer amino group. The similar polymer supports have been used for the synthesis of peptides and peptide-oligonucleotide conjugates [24-27]. Even the direct synthesis of peptide-oligonucleotide hybrids seems to be possible on this support, with the peptide chain elongation on the aminoalkyl part of the linker followed by the oligonucleotide synthesis at the $\mathrm{OH}$-linker arm.
Hence, the silica support containing the protected or dye-labeled amino group has been prepared with the use of uronium coupling reagent HBTU. The experiments on the synthesis of modified oligonucleotides on the proposed silica polymer support are in progress, and the results will be published elsewhere.

\section{Л. В. Дубей, I. я. дубей}

Отримання біфункціонального полімерного носія на основі силікагелю для синтезу $3^{\prime}$-мічених олігонуклеотидів

Резгоме

Описано спосіб отримання полімерного носія на основі силікагелю 3 лінкером, що містить захищені аміно- $i$ гідроксильну групи. В синтезі полімеру використано ефехтивний активуючий реагент гексафторфосфат 1-бензотріазолілокси-N, $N, N^{\prime}$, $N^{\prime}$-тетраметилуронію за присутності l-zідроксибензотріазолу (НОВТ). Такий біфункціональний носій зручний для отримання 3'-модифікованих олігонуклеотидів для пост-синтетинної кон'югачії та прямого твердофазного синтезу 3'мічених олігонуклеотидів. Синтезовано флуоресцеїн-модифікований силікагельний полімер.

Ключові слова полімерні носіі, онієві реасенти, мічені олігонуклеотиди.

\section{л. В. Дубей, и. Я. Дубей}

Получение бифункционального полимерного носителя на основе силикагеля для синтеза 3'-меченньх олитонуклеотидов

Резкме

Описан способ получения силикагельного полимерного носителя с линкером, содерхаиим защищенные амино- и гидроксильную группь. В кацестве зффективного активирующего реагента на нескольких стадиях синтеза полимера использовали гексафторфосфат 1-бензотриазолигокси- $N, N, N^{\prime}, N^{\prime}$-тетраметилурония в присутствии 1-гидроксибекзотриазола. Такой бифункииональный носитель удобен для получения 3'-аминомодифичированных олигонуклеотидов для пост-синтетической комъюгации и для прямого твердофазного синтеза $3^{\prime}$-меченньх олигонуклеотидов. Смнтезирован флуоресцеин-модифицированный силикагельньй полимер.

Клочевые слова: полимернье носители, ониевье реагенты, меченые олигонуклеотиды.

\section{REFERENCES}

1. Nucleic acids in chemistry and biology / Eds G. M. Blackburn, M. J. Gait.-Oxford: IRL press, 1996. -528 p.

2. Goodchild $J$. Conjugates of oligonucleotides and modified oligonucleotides: a review of their synthesis and properties // Bioconjugate Chem. -1990.-I.-P. 165-187.

3. Millar $D$. P. Fluorescence studies of DNA and RNA structure and dynamics $/ /$ Curr. Opin. Struct. Biol.-1996.-6.P. 322-326.

4. Haughland R. P. Handbook of fluorescent probes and research products.-Eugene: OR, 2003.-984 p.

5 . Beaucage $S$. $L$, Iyer $R$. $P$. The functionalization of oligonucleotides via phosphoramidite derivatives // Tetrahedron.1993.-49.-P. 1925-1963.

6. Korshun V. A., Berlin $Y u$ A. Introduction of nonradioactive 
reporter groups into synthetic oligonucleotides and their detection // Bioorg. Khim.-1994.-20.-P. 565-616.

7. Products for DNA Research Catalogue. Glen Research.-Sterling, 1999. $-64 \mathrm{p}$.

8. Vu H., Joyce N., Rieger M., Walker D., Goldknopf I., Hill T. $S$, Jayaraman $K$, Mulvey $D$. Use of phthaloyl protecting group for the automated synthesis of $3^{\prime}$ [(Hydroxypropyl)amino] and 3'-[(hydroxypropyl) triglycyl] oligonucleotide conjugates // Bloconjugate Chem.-1995.-6.-P. 599-607.

9. Dubey I. Y., Lyapina T. V., Galkin A. P., Fedoryak D. M. Preparation of highly efficient polymer support based on microspheric silica Silochrom-2 for solid phase synthesis of DNA fragments // Biopolimery i Kletka.-1993.-9, N 4.P. 26-31.

10. Matteucci $M$. D., Caruthers $M$. H. Synthesis of deoxyoligonucleotides on a polymer support // J. Amer. Chem. Soc.1981.-103.-P. 3185-3191.

11. Melenhofer J., Waki M., Heimer E. P., Lambros T. J., Makofske $R$. C., Chang C. Solid phase synthesis without repetitive acidolysis. Preparation of leucyl-alanyl-glycyl-valine using 9-fluorenylmethoxycarbonylamino acids // Int. J. Peptide Res. -1979 . - 13.-P. 35-42.

12. Behrens $C$., Dahl $O$. Synthesis of achiral linker reagents for direcl labelling of oligonucleotides on solid supports // Nucleosides and Nucleotides. -1999.-18.-P. 291-305.

13. Theisen P., McCollum $C$., Upadhya $K$, Jacobson $\mathcal{K}, V u H$. Andrus A. Fluorescent dye phosphoramidite labelling of oligonucleotides // Tetrahedron Lett.-1992._33.-P. 50335036.

14. Mullah B., Andrus $A$. Automated synthesis of double dyelabeled oligonucleotides using tetramethylrhodamine (TAMRA) solid supports // Tetrahedron Lett._1997._38.-P. 5751 5754.

15. Mullah B., Livak K, Andrus A., Keney P. Efficient synthesis of double dye-labeled oligodeoxyribonucleotide probes and their application in a real time PCR assay // Nucl. Acids Res.-1998.-26.-P. 1026-1031.

16. Albericio F., Bofill J. M., Elfaham A., Kates S. A. Use of onium salt-based coupling reagents in peptide synthesis // J. Org. Chem. $-1998 .-63 .-P .9678 \rightarrow 9683$.

17. Pon R. T., Yu S., Sanghvi $Y, S$. Rapid esterification of nucleosides to solid-phase supports for oligonucleotide syn- thesis using uronium and phosphonium coupling reagents // Bioconjugate Chem.-1999.-10.-P. 1051-1057.

18. Pon $R$. T., Yu S., Guo Z., Sanghvi Y. S. Multiple oligodeoxyribonucleotide syntheses on a reusable solid-phase CPG support via the hydroquinone- $0, O^{\prime}$-diacetic acid (Q-linker) linker arm // Nucl. Acids Res.-1999.-27.-P. 1531-1538.

19. McMinn D. L., Greenberg $M$. $M$. Postsynthetic conjugation of protected oligonucleotides containing $3^{\prime}$-alkylamines $/ / \mathrm{J}$. Amer. Chem. Soc.-1998. - 120.-P. 3289-3294.

20. Kahl J. D., McMinn D. L, Greenberg $M$. $M$. High-yielding method for on-column derivatization of protected oligodeoxymucleotides and its application to the convergent synthesis of 5',3'-bis-conjugates // J. Org. Chem.-1998.-63.P. 4870-4871.

21. Dubey I., Pratviel G., Meunier B. Preparation of cationic non-metallated- or zinc-porphyrin-oligonucleotide fluorescent conjugates // Compt. Rend. Acad. Sci. (Paris).-1998.-1.P. 259-267.

22. Dubey L. V., Dubey $I$. Y. Onium salts as coupling reagents in the preparation of silica polymer supports for solid phase oligonucleotide synthesis // Ukr. Bloorg. Acta.-2002.-1, N 1.-P. 13-20.

23. Van Aershot A., Herdewijn $P$., Vanderhaeghe $H$. Silica gel functionalised with different spacers as solid support for oligonucleotide synthesis // Nucleosides and Nucleotides.1988. -7.-P. 75-90.

24. Fmoc solid phase peptide synthesis: a practical approach / Eds W. C. Chan, P. D. White-COxford: Univ. press, 2000.-288 p.

25. Bergmann $F$., Bannwarth $W$. Solid phase synthesis of directly linked peptide-oligonucleotide hybrids using standard synthesis protocols // Tetrahedron Lett. - 1995. - 36. -P. 1839-1842.

26. Stetsenko D. A., Gait $M$. J. A convenient solid-phase method for synthesis of 3 '-conjugates of oligonucleotides // Bioconjugate Chem.-2001.-12.-P. 576-586

27. Stetsenko D. A., Malakhov A. D., Gait M. J. Total stepwise solid-phase synthesis of oligonucleotide-( $\left.3^{\circ}-\mathrm{N}\right)$-peptide conjugates // Org. Lett. -2002.-4.-P, 3259-3262.

удК 577.113.6:542.95

Надійпла до редакціі 23.03.04 